\title{
Effects of bromides of potassium and ammonium on some crops
}

Irina Shtangeeva ${ }^{\mathrm{a}, *}$, Matti Niemelä ${ }^{\mathrm{b}}$, and Paavo Perämäki ${ }^{\mathrm{b}}$

${ }^{a}$ Institute of Earth Sciences, St. Petersburg University; ${ }^{b}$ Research Unit of Sustainable Chemistry, University of Oulu, Finland

* Corresponding author. E-mail: shtangeeva@gmail.com

\section{ABSTRACT}

In this work, the response of wheat (Triticum aestivum L.), rye (Secale cereale L.), oat (Avena sativa L.), and pea (Pisum sativum L.) to bromides of potassium ( $\mathrm{KBr}$ ) and ammonium $\left(\mathrm{NH}_{4} \mathrm{Br}\right)$ was studied. All plants were capable of accumulating high concentrations of bromine $(\mathrm{Br})$. However, the $\mathrm{Br}$ accumulation depended on the $\mathrm{Br}$ compounds presented in the growth medium and plant species. The highest Br concentrations were observed in leaves and roots of the seedlings germinated in the medium spiked with $\mathrm{KBr}$. Oat accumulated more $\mathrm{Br}$ than other plants and the lowest $\mathrm{Br}$ accumulation was observed in pea. The bioaccumulation of $\mathrm{Br}$ resulted in suppression of plant biomass and concentrations of several essential nutrients (K, Na, Ca, $\mathrm{Mg}, \mathrm{Zn}$ and $\mathrm{Cl}$ ). The most negative effects were caused by $\mathrm{NH}_{4} \mathrm{Br}$. Probably, this action was due to cumulative effects of $\mathrm{Br}^{-}$and $\mathrm{NH}_{4}^{+}$. Among other plant species, the most tolerant to bromides was oat and the most sensitive was wheat.

KEYWORDS bromides; bromine bioaccumulation; nutrients; plant biomass

Introduction

Bromine $(\mathrm{Br})$ is the $44^{\text {th }}$ most common element in the Earth's crust. It occurs widely as soluble bromide salts in sea water, salt lakes, and underground brine deposits associated with oil. There are also numerous known organobromine compounds synthesized by living organisms 
or formed during natural abiotic processes (Moreno et al. 2015). Bromides are commonly found in the environment along with sodium chloride, owing to their similar physical and chemical properties, but in smaller quantities.

Worldwide production of $\mathrm{Br}$ compounds is estimated to be around 330,000 tons per year (Ross 2017). Meanwhile, it was shown that bromides are persistent in the environment, accumulate in the food chain and are of toxicological concern. The application of $\mathrm{Br}$ containing chemicals in industry and agriculture resulted in an increase of $\mathrm{Br}$ content in soil (Honaganahallia and Seiber 1996; Venkatesan and Halden 2014; Wisniak 2002). Plants growing in the soil demonstrated a considerable accumulation of $\mathrm{Br}$ compared to concentration of the trace element in plants growing in clean soil (da Rosa Couto et al. 2018; Djingova et al. 1986; Eljarrat et al. 2008; Huang, Zhang and Christie 2011; Mueller et al. 2006; Yang et al. 2017).

It was shown (McCall et al. 2014) that $\mathrm{Br}$ is a new essential trace element for humans and animals. Although various plant species are capable of accumulating high concentrations of $\mathrm{Br}$, according to our knowledge, its role in plants has not been identified. At the moment we can state only that $\mathrm{Br}$ is a constituent of all plant tissues. However, there is no real evidence yet to support the view that $\mathrm{Br}$ is concerned with any function in a plant. Thus, the question why plants have evolved the accumulation mechanism for $\mathrm{Br}$ as well as $\mathrm{Br}$ requirements of different plant species and its possible toxicity should be considered.

The aims of the research were (1) to assess the response of several plant species to the increase of $\mathrm{Br}$ concentration in the growth medium and (2) to study the factors responsible for uptake and accumulation of $\mathrm{Br}$ in the plants that were exposed to bromides of potassium $(\mathrm{KBr})$ or ammonium $\left(\mathrm{NH}_{4} \mathrm{Br}\right)$. The purpose was to estimate effects of both $\mathrm{Br}^{-}$and other components (cations) of the compounds on the plant development and nutrition. The challenge was to test if the cations influence on the distribution of $\mathrm{Br}$ in the plants. 
Among selected bromides, potassium bromide was used more often for experiments on uptake of Br by plants (Berry and Steward 1934; Buwalda, Stribley and Tinker 1983; Schnabel, Stout and Shaffer 1995; Sharratt and Knight 2005). Less information is available on effects of ammonium bromide on plants (Jacoby 1965; Wetchagarun et al. 2017). It is known that $\mathrm{NH}_{4} \mathrm{Br}$ fully dissociates in aquatic environment to bromide and ammonium ions (Speight 2016).

The young seedling stage is the most nutrient-sensitive stage for a plant (Lee et al. 2007; Shamshad et al. 2018). Therefore, it would be useful to assess possible effects of Br exposure in the course of the first stages of the plant development.

Materials and methods

\section{Experimental design}

Seeds of wheat (Triticum aestivum L.), rye (Secale cereale L.), oat (Avena sativa L.), and pea (Pisum sativum L.) were surface sterilized by two 3-min soakings with gentle stirring in commercial bleach $(5.25 \% \mathrm{NaOCI})$. The seeds were then rinsed three times in sterile doubledistilled water to remove surface sterilization agents. After surface sterilization, the seeds were placed on a filter paper in Petri dishes (diameter $150 \mathrm{~mm}$, height $30 \mathrm{~mm}$ ). The filter paper was moistened with a sufficient amount of water or with water spiked with either $\mathrm{KBr}$ or $\mathrm{NH}_{4} \mathrm{Br}$. The chemicals were acquired from Roschimreactive, St. Petersburg (Russia) as pure standards ( $99 \%$ of purity). Concentration of $\mathrm{Br}$ in the growth media was $50 \mathrm{mg} \mathrm{L}^{-1}$. After 5 days, first series of plant samples was collected, and the rest of the seedlings was transferred into plastic pots filled with $1 \mathrm{~L}$ of water without bromides or water spiked with the same amount of $\mathrm{KBr}$ or $\mathrm{NH}_{4} \mathrm{Br}$. The seedlings were grown in the pots during 8 additional days. We did not add any nutrients to the growth media in the course of the experiments. The temperature in a naturally illuminated greenhouse was typically $25^{\circ} \mathrm{C}$ during the day $(16 \mathrm{~h}$ 
light period/day) and $22^{\circ} \mathrm{C}$ at night. At the end of experiments the $\mathrm{pH}\left(1: 2.5 \mathrm{H}_{2} \mathrm{O}\right)$ of the growth media was determined. The experiments were performed in triplicate (three replicates in one experiment). The plants (leaves and especially roots) were washed carefully just after sampling and air-dried up to constant weight.

\section{Elemental analysis}

Concentrations of $\mathrm{Br}$, chlorine $(\mathrm{Cl})$, and iodine $(\mathrm{I})$ in the plant samples were determined by ICP-MS and concentrations of sodium $(\mathrm{Na})$, magnesium $(\mathrm{Mg})$, phosphorus $(\mathrm{P})$, potassium $(\mathrm{K})$, calcium $\mathrm{Ca})$, and zinc $(\mathrm{Zn})$ were determined by ICP-OES after leaching the samples with tetramethyl ammonium hydroxide at mild temperature using the method described by Tagami et al. (2006). Detailed description of the procedure is given in our previous publications (Shtangeeva et al. 2015; Shtangeeva et al. 2017). Quality control was performed through concurrent analysis of certified reference material (CRM) NIST SRM 1573a (Tomato leaves). The results obtained for the CRM were in a good agreement with the reported certified and informative values.

\section{Data analysis}

The experimental results were analyzed by variance analysis using the least-significant difference test (Statistica for Windows 6.0 Software packages, StatSoft, Tulsa, OK, USA). The differences between groups of samples were considered significant at $\mathrm{P} \leq 0.05$ and the means were separated using a Fisher's protected least significant difference (LSD) test. Additionally, Pearson correlation analysis was applied to the data sets to assess the contribution of specific factors that may have an effect on distribution and relationships between $\mathrm{Br}$ and other elements in different parts of the plants. The correlation coefficient (r) and its significance was tested by $t$-test at $5 \%$ probability of error. 
Results and discussion

Effects of $\mathrm{Br}$ on the biomass of plants

Physiological measurements of plants often are based on the plant growth or growth inhibition. According to available literature, the effects of $\mathrm{Br}$ on the plant development may be rather different and result in either suppression or stimulation of the plant growth (BasoCejas et al. 2007; Fransi et al. 1987; Pawłowska and Biczak 2016; Shtangeeva et al. 2015; Stelmach 1959).

Our previous experiments with wheat and pea seedlings grown in the water spiked with $\mathrm{KBr}$ demonstrated that this bromide did not affect negatively the plant biomass (Shtangeeva et al. 2015). As it is seen from Fig. 1, similar situation was observed for rye and oat seedlings germinated in the medium spiked with $\mathrm{KBr}$. Leaf biomass of the rye seedlings germinated in the medium enriched with $\mathrm{KBr}$ even increased compared to biomass of leaves of the rye seedlings germinated in the medium not spiked with bromides. It was reported that the germination of 11 different crop species was not inhibited by $\mathrm{KBr}$ at concentrations below $500 \mathrm{mg} \mathrm{L}^{-1}$ (Bowman et al. 1997). On the other hand, the reaction of plants on $\mathrm{NH}_{4} \mathrm{Br}$ was different and depended on the plant species. The leaf biomass of rye and wheat seedlings germinated in the $\mathrm{NH}_{4} \mathrm{Br}$-spiked medium was similar to the biomass of the plants not treated with bromides. The biomass of leaves of oat and pea seedlings that were germinated in the medium spiked with $\mathrm{NH}_{4} \mathrm{Br}$ decreased statistically significantly $(\mathrm{P} \leq 0.05)$ compared to the biomass of leaves of the seedlings germinated in the medium without bromides, and the seedlings germinated in the medium spiked with $\mathrm{KBr}$. It may be assumed that the combined exposure to $\mathrm{Br}^{-}$and $\mathrm{NH}_{4}{ }^{+}$was toxic for these plant species.

Ammonium can affect different physiological and biochemical processes in plants. Under high concentrations, ammonium nutrition can lead to various growth responses including 
restricted plant growth (Dominguez-Valdivia et al. 2008; Horchani, Hajri and Aschi-Smiti 2011). The symptoms of toxicity, however, differ widely among plant species. It was reported that pea was one of the most sensitive to $\mathrm{NH}_{4}{ }^{+}$toxicity, especially in terms of its effect on growth rates (Britto and Kronzucke 2002).

\section{Bromine accumulation in different plant species}

For our experiments we used four plant species - wheat, rye, oat, and pea. One of the plants, pea, belongs to Dicotyledons, while others are Monocotyledons. It has been speculated that each plant species has developed a specific element composition, and it reflects first of all plant nutrient requirements rather than nutrient availability in the soil (Garten 1978; Markert 1989). One of the reasons for separation of plant species at physiological and biochemical level may be difference in concentrations of macro- and trace elements in a particular plant species. Different plants are capable of maintaining rather stable cytosolic concentrations of nutrients in their tissues that can differ from one to another plant species (Mengel and Kirkby 2001). Therefore, we may expect certain differences in the biochemical processes (including accumulation of $\mathrm{Br}$ ) occurring in the plants that belong to different botanical taxa. Notice that compared to other selected plant species, more information is available on $\mathrm{Br}$ uptake and its phytotoxicity to wheat (Buwalda, Stribley and Tinker 1983; Fransi et al. 1987; Ottman and Pope 2000).

The seedlings germinated in the media spiked with bromides were capable of accumulating high concentrations of $\mathrm{Br}$. The level of $\mathrm{Br}$ accumulation, however, depended on the plant species. The highest concentration of $\mathrm{Br}$ was in roots and leaves of oat, and the least $\mathrm{Br}$ accumulation was in pea (Table 1). These results confirm data of our previous experiments with pea and wheat seedlings grown in the water spiked with $\mathrm{KBr}$. It was shown that the wheat accumulated more $\mathrm{Br}$ than the pea (Shtangeeva et al. 2015). The mean $\mathrm{Br}$ 
concentrations in the 7-day-old wheat and pea seedlings grown in the water spiked with 50 $\mathrm{mg} \mathrm{L} \mathrm{L}^{-1}$ of Br were $4320 \mathrm{mg} \mathrm{kg}^{-1}$ and $1080 \mathrm{mg} \mathrm{kg}^{-1}$ in roots and leaves of pea seedlings, respectively and $18200 \mathrm{mg} \mathrm{kg}^{-1}$ and $33600 \mathrm{mg} \mathrm{kg}^{-1}$ in roots and leaves of wheat seedlings, respectively.

Reported concentrations of $\mathrm{Br}$ in the plants growing in soils contaminated with bromides usually do not exceed 1000-2000 $\mathrm{mg} \mathrm{kg}^{-1}$ (Kabata-Pendias 2011). These concentrations are lower than those that we recorded in our experiments. It is known that metals and metalloids may be adsorbed on the surface of the soil particles (Bradl 2004; Violante et al. 2010). Similar effects were observed for bromides (Ahn et al. 2006; Bailey and White 1964). Thus, plants growing in soil are able to absorb less $\mathrm{Br}$ than they can absorb from liquid medium where $\mathrm{Br}$ is present in easily available form. For example, $\mathrm{Br}$ concentrations in plants grown in soils uncontaminated with $\mathrm{Br}$ usually do not exceed $40 \mathrm{mg} \mathrm{kg}^{-1}$ (Låg and Steinnes 1977; Pourimani et al. 2013; Wiskerman 2006; Yuita et al. 1982), whereas concentration of $\mathrm{Br}$ in seaweeds collected from uncontaminated sites may be as high as $2000 \mathrm{mg} \mathrm{kg}^{-1}$ (Küpper et al. 2013).

The accumulation of $\mathrm{Br}$ also depended on bromides present in the growth medium. All of the plants accumulated more $\mathrm{Br}$ if they were germinated in the $\mathrm{KBr}$-spiked medium than in the medium spiked with $\mathrm{NH}_{4} \mathrm{Br}$ (with the exception of leaves of pea). Previous experiments (Shtangeeva et al. 2015) showed that in most cases plants accumulate more Br if they are grown in the medium spiked with $\mathrm{KBr}$ than if plants are grown in a $\mathrm{NaBr}$-spiked medium.

\section{Effects of different bromides on the concentrations of other elements in plants}

The concentration of nutrients in a plant is an important physiological parameter. Our experiments revealed a suppression in the concentrations of several key elements required for the plant growth $(\mathrm{K}, \mathrm{Na}, \mathrm{Ca}, \mathrm{Mg}, \mathrm{Zn}$, and $\mathrm{Cl}$ ) caused by bromides (Table 1). It may be assumed that this limitation in accumulation of the nutrients might result from the 
bioaccumulation of Br. However, our previous tests (Shtangeeva 2017) showed that $\mathrm{Br}$ concentration in young wheat seedlings grown in different liquid media (distilled water, spring water, nutrient solution of Hoagland) were similar. Besides, the four plant species selected for our experiments had large seeds and could grow for 13 days without supply of nutrients. Nevertheless, there is a chance that the seedlings might be nutrient-deficient to some extent, and this deficiency could affect the uptake of $\mathrm{Br}$ and other elements.

In response to the $\mathrm{Br}$ bioaccumulation concentration of $\mathrm{Cl}$ in roots and leaves of pea and wheat seedlings germinated in the media spiked with $\mathrm{NH}_{4} \mathrm{Br}$ decreased statistically significantly $(\mathrm{P} \leq 0.05)$ compared to $\mathrm{Cl}$ content in the seedlings germinated without bromides. Besides, a statistically significant decrease of $\mathrm{Cl}$ content occurred in roots of the rye seedlings germinated in the media enriched with different bromides. There were no consequences of $\mathrm{Br}$ accumulation on the content of $\mathrm{Cl}$ in oat seedlings.

As one might expect, an addition of $\mathrm{KBr}$ to the growth medium resulted not only in an increase of $\mathrm{Br}$ concentration in plants but also in a statistically significant increase of $\mathrm{K}$ content in roots and leaves of all the plants with the exception of pea. In oat, a significant $(\mathrm{P} \leq 0.05)$ increase of $\mathrm{K}$ concentration was also observed in the seedlings germinated in the medium spiked with $\mathrm{NH}_{4} \mathrm{Br}$. On the other hand, concentration of $\mathrm{K}$ in roots of the pea seedlings germinated in the medium spiked with $\mathrm{NH}_{4} \mathrm{Br}$ decreased statistically significantly $(\mathrm{P} \leq 0.05)$ compared with $\mathrm{K}$ concentration in roots of the plants grown without bromides.

It is interesting to note that the level of increase of $\mathrm{Br}$ and $\mathrm{K}$ concentrations in the plants exposed to $\mathrm{KBr}$ was not the same. It may be assumed that unequal uptake of $\mathrm{Br}$ and $\mathrm{K}$ could arise from the superimposed effect of two distinct processes, one of which caused the uptake of $\mathrm{Br}$ only and another caused an equal uptake of $\mathrm{K}$ and $\mathrm{Br}$. Similar effect was described by Steward and Harrison (1939) on absorption of $\mathrm{RbBr}$ in potato. Notice that $\mathrm{Rb}$ is chemically similar to $\mathrm{K}$. Our previous experiments on effects of $\mathrm{KBr}$ on accumulation of $\mathrm{Br}$ and $\mathrm{K}$ in 
wheat and pea seedlings grown in water culture also demonstrated higher level of accumulation of $\mathrm{Br}$ than $\mathrm{K}$ in the plants (Shtangeeva et al. 2015). It was reported (Jackson and Adams 1963) that the cation absorption rates may be independent on the concentrations and rates of absorption of the anions of the external solution, and cations may be absorbed independently on the anions of the solution where plants are grown in exchange with $\mathrm{H}^{+}$, while anions are exchanged with $\mathrm{OH}^{-}$.

In several cases the concentration of $\mathrm{Ca}$ in the seedlings germinated in the Br-spiked media was restricted compared to the $\mathrm{Ca}$ content in roots and leaves of the plants grown without bromides. The bioaccumulation of $\mathrm{Br}$ negatively affected the concentration of $\mathrm{Na}$ in roots of wheat. In rye seedlings, a statistically significant $(\mathrm{P} \leq 0.05)$ suppression of root $\mathrm{Na}$ content was observed only if the seedlings were germinated in the medium spiked with $\mathrm{NH}_{4} \mathrm{Br}$. In wheat, different $\mathrm{Br}$ compounds also influenced the $\mathrm{Zn}$ concentration in roots. In roots of pea, concentration of $\mathrm{Zn}$ was statistically significantly $(\mathrm{P} \leq 0.05)$ lower in the seedlings germinated in the medium spiked with $\mathrm{NH}_{4} \mathrm{Br}$ compared to $\mathrm{Zn}$ concentration in roots of the seedlings germinated in the medium spiked with $\mathrm{KBr}$ and in water not spiked with bromides. Bromides affected concentration of $\mathrm{Mg}$ in roots of wheat seedlings. It decreased statistically significantly $(\mathrm{P} \leq 0.05)$ compared with concentration of $\mathrm{Mg}$ in roots of the seedlings germinated without bromides. The suppression of $\mathrm{Mg}$ concentration was observed also in leaves of wheat seedlings germinated in the medium spiked with $\mathrm{NH}_{4} \mathrm{Br}$.

Considering that roots were in an immediate contact with bromides it is not surprising that they suffered more than leaves. Besides, different plant species responded differently to an increased concentration of $\mathrm{Br}$ in the growth medium. Probably, one of the reasons might be that concentration of one or another element can be different in different plant species (Barker and Pilbeam 2015). In our experiments, more serious consequences were observed for the seedlings germinated in the medium spiked with $\mathrm{NH}_{4} \mathrm{Br}$. It may be hypothesized that this 
action was due to cumulative effect of $\mathrm{Br}^{-}$and $\mathrm{NH}_{4}{ }^{+}$. Among other plant species, the most tolerant plant was oat and the most sensitive to bromides was wheat.

\section{Temporal variations of Br in plants}

The seedlings germinated in the Br-spiked media accumulated more Br with time. After 5 days of germination, all plants accumulated more $\mathrm{Br}$ in roots than in leaves. Then, in the 8 days that followed, the $\mathrm{Br}$ concentration in leaves of the seedlings germinated in the media spiked with $\mathrm{KBr}$ and $\mathrm{NH}_{4} \mathrm{Br}$ increased much more than in roots. Typical variations in the $\mathrm{Br}$ concentrations are shown in Fig. 2 on the example of rye seedlings. The highest level of $\mathrm{Br}$ accumulation was observed when the seedlings were germinated in the medium spiked with $\mathrm{KBr}$. If the seedlings were germinated in the medium spiked with $\mathrm{NH}_{4} \mathrm{Br}$ the accumulation of $\mathrm{Br}$ was less by almost half. In the course of the experiments, concentration of $\mathrm{Br}$ increased in roots and in leaves. However, the increase of $\mathrm{Br}$ content in leaves of the seedlings germinated in the media spiked with bromides was greater than in roots with time. It may be suggested that by the end of the experiments concentration of $\mathrm{Br}$ in roots has reached possible limit. Roots were unable to protect upper plant parts from translocation of $\mathrm{Br}$. A large part of the trace element was transferred from roots to leaves.

\section{Variations in the pH of the growth media}

By the end of the experiments the $\mathrm{pH}$ values of the growth media were similar for untreated and $\mathrm{KBr}$-spiked media (Fig. 3). The $\mathrm{pH}$ values of the media that were spiked with bromide of ammonium were statistically significantly $(\mathrm{P} \leq 0.05)$ lower compared to the $\mathrm{pH}$ of the medium not spiked with bromides. Probably, this phenomenon might be due to the fact that ammonium ion is a weak acid. Besides, the $\mathrm{pH}$ of the media where pea seedlings were germinated was lower than the $\mathrm{pH}$ of the media with other plants. It may be suggested that 
root exudates of pea released to the surrounding medium more acid components than other plant species. Marked changes in the $\mathrm{pH}$ of the culture media also may be due to unequal absorption of cations and anions (Jacobson et al. 1957; Hribar et al. 2002).

\section{Correlation between elements in plants}

Results of correlation analysis demonstrated an excellent correlation between concentrations of $\mathrm{Br}$ in roots and in leaves $(\mathrm{r}=0.84, \mathrm{P} \leq 0.05)$. A statistically significant $(\mathrm{P} \leq 0.05)$ positive correlation between concentrations of elements in roots and leaves occurred for $\mathrm{Cl}(\mathrm{r}=0.79)$, $\mathrm{Na}(\mathrm{r}=0.67), \mathrm{Zn}(\mathrm{r}=0.47), \mathrm{K}(\mathrm{r}=0.41)$, and $\mathrm{P}(\mathrm{r}=0.39)$.

Calculation of correlation coefficients between $\mathrm{Br}$ and other elements in different plant parts demonstrated a statistically significant positive correlation between $\mathrm{Br}$ and $\mathrm{Na}(\mathrm{r}=0.43)$ in roots. In leaves, a statistically significant positive correlation was observed between $\mathrm{Br}$ and $\mathrm{Cl}(\mathrm{r}=0.48)$ and between $\mathrm{Br}$ and $\mathrm{K}(\mathrm{r}=0.54)$.

\section{Conclusion}

Plants were capable of accumulating rather high concentrations of $\mathrm{Br}$ if they were grown in the aqueous media enriched with different bromides. The accumulation of $\mathrm{Br}$ negatively affected the plant biomass and also resulted in a decrease of concentrations of nutrients in the plants. The most significant negative effects were caused by ammonium bromide. Oat was the most tolerant and wheat was the most sensitive to the bromide actions.

\section{Acknowledgements}

The authors are grateful to Mrs Seija Liikanen (Research Unit of Sustainable Chemistry, University of Oulu) for helping with sample analyses. 
Finding

This study was supported by Academy of Finland (grant N 297769) and St. Petersburg University (grant N 18.42.957.2016). Irina Shtangeeva acknowledges a partly support of this work by Russian Foundation of Basic Research (grant N 18-53-80010) providing her a possibility to perform greenhouse experiments.

\section{References}

Ahn, M-Y., T. R. Filley, C. T. Jafvert, L. Nies, I. Hua, and J. Bezares-Cruz. 2006. Photodegradation of decabromodiphenyl ether adsorbed onto clay minerals, metal oxides, and sediment. Environmental Science \& Technololy 40 (1):215-220. doi: 10.1021/es051415t.

Bailey, G. W., and J. L. White. 1964. Soil-pesticide relationships, adsorption and desorption of organic pesticides by soil colloids, with implications concerning pesticide bioactivity. Journal of Agricultural and Food Chemistry 12 (4):324-332. doi: 10.1021/jf60134a007.

Barker, A. V., and D. J. Pilbeam. 2015. Handbook of plant nutrition, second ed. 6000 Broken Sound Parkway NW, Suite 300 Boca Raton, FL 33487-2742: CRC Press Taylor \& Francis Group.

Baso-Cejas, E., G. Brito, C. Díaz, and E. M. Peña-Méndez. 2007. Determination of inorganic bromide content in several vegetable foods. Bulletin of Environmental Contamination and Toxicology 78 (5):417-420. doi: 10.1007/s00128-007-9212-9.

Berry, W. E., and F. C. Steward. 1934. The absorption and accumulation of solutes by living plant cells: VI. The absorption of potassium bromide from dilute solution by tissue from various plant storage organs. Annals of Botany 48 (190):395-410. https://doi.org/10.1093/oxfordjournals.aob.a090452. 
Bowman, R. S., J. Schroeder, R. Bulusu, M. Remmenga, and R. Heightman. 1997. Plant toxicity and plant uptake of fluorobenzoate and bromide water tracers. Journal of Environmental Quality 26 (5):1292-1299. doi: 10.2134/jeq1997.00472425002600050015x.

Bradl, H. B. 2004. Adsorption of heavy metal ions on soils and soils constituents. Journal of Colloid and Interface Science 277:1-18. https://doi.org/10.1016/j.jcis.2004.04.005.

Britto, D. T., and H. J. Kronzucker. 2002. $\mathrm{NH}_{4}{ }^{+}$toxicity in higher plants: a critical review. Journal of Plant Physiology 159:567-584. doi: 10.1078/0176-1617-0774.

Buwalda, J. G., D. P. Stribley, and P. B. Tinker. 1983. Increased uptake of bromide and chloride by plants infected with vesicular-arbuscular mycorrhizas. New Phytologist 93 (2): 217-225.

Da Rosa Couto, R., J. Faversani, C. A. Ceretta, P. A. A. Ferreira, C. Marchezan, D. B. Facco, L. P. Garlet, J. S. Silva, J. J. Comin, C. A. Bizzi, E. M. M. Flores, and G. Brunetto. 2018. Health risk assessment and soil and plant heavy metal and bromine contents in field plots after ten years of organic and mineral fertilization. Ecotoxicology and Environmental Safety 153:142-150. doi: 10.1016/j.ecoenv.2018.01.046.

Djingova, R., I. Kuleff, I. Penev, and B. Sansoni. 1986. Bromine, copper, manganese and lead content of the leaves of Taraxacum officinale (dandelion). Science of the Total Environment 50:197-208. doi: 10.1016/0048-9697(86)90361-X.

Domínguez-Valdivia, M. D., P. M. Aparicio-Tejo, C. Lamsfus, C. Cruz, M. A. MartinsLoução, and J. F. Moran. 2008. Nitrogen nutrition and antioxidant metabolism in ammoniumtolerant and -sensitive plants. Physiologia Plantarum 132:359-369. doi: 10.1111/j.13993054.2007.01022.x.

Eljarrat, E., G. Marsh, A. Labandeira, and D. Barceló. 2008. Effect of sewage sludges contaminated with polybrominated diphenylethers on agricultural soils. Chemosphere 71 (6): 1079-1086. 
Fransi, A., R. Pons, A. Sala, V. R. Vallejo, and C. Bertran. 1987. Wheat and soil bromide dynamics after fumigation with methyl bromide in a mediterranean climate. Plant and Soil $98(3): 417-424$.

Garten, C. T. Jr. 1978. Multivariate perspectives on the ecology of plant mineral element composition. The American Naturalist 112:533-544. https://doi.org/10.1086/283295.

Honaganahalli, P. S., and J. N. Seiber. 1996. Health and environmental concerns over the use of fumigants in agriculture: The case of methyl bromide. In Fumigants: Environmental Fates, Exposure and Analysis, ed. J. N. Seiber, J. A. Knuteson, J. E. Woodrow, N. L. Wolfe, M. V. Yates, and S. R. Yates, 1-13. Washington, DC: ACS Symposium Series, American Chemical Society.

Horchani, F., R. Hajri, and S. Aschi-Smiti. 2011. Is the sensitivity to ammonium nutrition related to nitrogen accumulation? Current Botany 2 (2):18-22.

Hribar, B., N. T. Southall, V. Vlachy, and K. A. Dill. 2002. How ions affect the structure of water. Journal of the American Chemical Society 124 (41):12302-12311. doi: $10.1021 / \mathrm{ja} 026014 \mathrm{~h}$.

Huang, H., S. Zhang, and P. Christie. 2011. Plant uptake and dissipation of PBDEs in the soils of electronic waste recycling sites. Environmental Pollution 159:238-243. doi: 10.1016/j.envpol.2010.08.034.

Jackson, P. C., and H. R. Adams. 1963. Cation-anion balance during potassium and sodium absorption by barley roots. Journal of General Physiology 46:369-386.

Jacobson, L., R. Overstreet, R. M. Carlson, and J. A. Chastain. 1957. The effect of pH and temperature on the absorption of potassium and bromide by barley roots. Plant Physiology 32:658-662.

Jacoby, B. 1965. The effect of ATP on uptake of monovalent cations and anions by red beet slices. Journal of Experimental Botany 16 (47):243-248. doi: 10.1093/jxb/16.2.243. 
Kabata-Pendias, A. 2011. Trace elements in soils and plants, 4th edn., Boca Raton, Fl: CRC.

Küpper, F. C., L. J. Carpenter, C. Leblanc, C. Toyama, Y. Uchida, B. H. Maskrey, J. Robinson, E. F. Verhaeghe, G. Malin, G. W. $3^{\text {rd }}$ Luther, et al. 2013. In vivo speciation studies and antioxidant properties of bromine in Laminaria digitatareinforce the significance of iodine accumulation for kelps. Journal of Experimental Botany 64 (10):2653-2664. doi: 10.1093/jxb/ert110.

Låg, J., and E. Steinnes. 1977. Halogens in barley and wheat grown at different locations in Norway. Acta Agriculturae Scandinavica $27 \quad$ (4):265-268. doi: $10.1080 / 00015127709435138$.

Lee, S. Y., J. H. Ahn, Y. S. Cha, D. W. Yun, M. C. Lee, J. C. Ko, K. S. Lee, and M. Y. Eun. 2007. Mapping QTLs related to salinity tolerance of rice at the young seedling stage. Plant Breeding 126 (1):43-46. doi: 10.5376/mpb.2014.05.009.

Markert, B. 1989. Multi-element analysis in ecosystems: basic conditions for representative sampling of plant materials. Fresenius' Zeitschrift für analytische Chemie 335:562-565. https://doi.org/10.1007/BF00474249.

McCall, A. S., C. F. Cummings, G. Bhave, R. Vanacore, A. Page-McCaw, and B. G. Hudson. 2014. Bromine is an essential trace element for assembly of collagen IV scaffolds in tissue development and architecture. Cell 157 (6):1380-1392. doi: 10.1016/j.cell.2014.05.009.

Mengel, K., and E. A. Kirkby. 2001. Principles of plant nutrition, 5th edn. Dordrecht: Kluwer Academic Publishers.

Moreno J., F. Fatela, E. Leorri, M. F. Araújo, F. Moreno, J. De la Rosa, M.C. Freitas, T. Valente, and D. R. Corbett. 2015. Bromine enrichment in marsh sediments as a marker of environmental changes driven by Grand Solar Minima and anthropogenic activity (Caminha, 
NW of Portugal). Science of the Total Environment 506-507:554-566. doi: 10.1016/j.scitotenv.2014.11.062.

Mueller, K. E., S. R. Mueller-Spitz, H. F. Henry, A. P. Vonderheide, R. S. Soman, B. K. Kinkle, and J. R. Shann. 2006. Fate of pentabrominated diphenyl ethers in soil: abiotic sorption, plant uptake, and the impact of interspecific plant interactions. Environmental Science \& Technology 40 (21):6662-6667. doi: 10.1021/es0607761.

Ottman, M. J., and N. V. Pope. 2000. Nitrogen fertilizer movement in the soil as influenced by nitrogen rate and timing in irrigated wheat. Soil Science Society of America Journal 64 (5):1883-1892. doi: 10.2136/sssaj2000.6451883x.

Pawłowska, B., and R. Biczak. 2016. Evaluation of the effect of tetraethylammonium bromide and chloride on the growth and development of terrestrial plants. Chemosphere 149: 24-33. doi: 10.1016/j.chemosphere.2016.01.072.

Pourimani, R., K. Abasnejad, K. Ghanbarzadeh, M. Reza Zare, and M. Kamali. 2013. Determining the amount of $\mathrm{Br}, \mathrm{Na}$ and $\mathrm{K}$ in six wheat samples with neutron activation analysis (NAA) method in Arak, I.R. Iran. Journal of Radioanalytical Nuclear Chemistry 295:163-166. doi: 10.1007/s10967-012-1867-y

Ross, R. 2017. Facts About Bromine. Live Science Contributor. Accessed 8 February 2017. https://www.livescience.com/32072-bromine.html.

Schnabel, R. E., W. L. Stout, and J. A. Shaffer. 1995. Uptake of a hydrologic tracer (bromide) by ryegrass from well and poorly-drained oils. Journal of Environmental Quality 24 (5):888-892. doi: 10.2134/jeq1995.00472425002400050015x. 
Shamshad, S, M. Shahid, M. Rafiq, S. Khalid, C. Dumat, M. Sabir, B. Murtaza, A. B. U. Farooq, and N. S. Shah. 2018. Effect of organic amendments on cadmium stress to pea: A multivariate comparison of germinating vs young seedlings and younger vs older leaves. Ecotoxicology and Environmental Safety 151:91-97. doi: 10.1016/j.ecoenv.2018.01.002.

Sharratt, B. S., and C. W. Knight. 2005. Dissipation of bromide and metribuzin affected by tillage and crop residue management in Subarctic Alaska. Arctic 58:260-267.

Shtangeeva, I., M. Niemelä, P. Perämäki, and S. Timofeev. 2015. Response of wheat and pea seedlings on increase of bromine concentration in the growth medium. Environmental Science and Pollution Research 22:19060-19068. doi: 10.1007/s11356-015-5106-2.

Shtangeeva, I., M. Niemelä, P. Perämäki, A. Ryumin, S. Timofeev, S. Chukov, and G. Kasatkina. 2017. Phytoextration of bromine from contaminated soil. Journal of Geochemical Exploration 174:21-28. doi: 10.1016/j.gexplo.2016.03.012.

Shtangeeva, I. 2017. Bromine accumulation in some crops and grasses as determined by neutron activation analysis. Communications in Soil Science and Plant Analysis 48 (19): 2338-2346. doi: 10.1080/00103624.2017.1411511.

Speight, J. G. 2016. Environmental organic chemistry for engineers. Amsterdam: Elsevier.

Stelmach, A. 1959. Bromine retention in some soils and uptake of bromine by plants after soil fumigation. Soil Science 88 (2):61-66. doi: 10.1097/00010694-195988020-00001.

Steward, F. C., and J. A. Harrison. 1939. The absorption and accumulation of salts by living plant cells: IX the absorption of rubidium bromide by potato discs. Annals of Botany 3 (2):427-53. https://doi.org/10.1093/oxfordjournals.aob.a085068.

Tagami, K., S. Uchida, I. Hirai, H. Tsukada, and H. Takeda. 2006. Determination of chlorine, bromine and iodine in plant samples by inductively coupled plasma-mass 
spectrometry after leaching with tetramethyl ammonium hydroxide under a mild temperature condition. Analytica Chimica Acta 570 (1):88-92. doi: 10.1016/j.aca.2006.04.011.

Venkatesan, A. K., and R. U. Halden. 2014. Brominated flame retardants in U.S. biosolids from the EPA national sewage sludge survey and chemical persistence in outdoor soil mesocosms. Water Research 55:133-142. doi: 10.1016/j.watres.2014.02.021.

Wetchagarun, S., C. Tippayakul, A. Petchrak, K. Sukrod, and P. Khoonkamjorn. 2017. A study of residence time distribution using radiotracer technique in the large scale plant facility. Journal of Physics: Conference Series 860 012015, 1-5. doi: 10.1088/1742$6596 / 860 / 1 / 012015$

Wishkerman, A. 2006. Bromine and iodine in plant-soil systems. PhD diss., Universität Heidelberg.

Wisniak, J. 2002. The history of bromine from discovery to commodity. Indian Journal of Chemical Technology 9 (3):263-271.

Violante, A., V. Cozzolino, L. Perelomov, A. G. Caporale, and M. Pigna. 2010. Mobility and bioavailability of heavy metals and metalloids in soil environments. Journal of Soil Science and Plant Nutrition 10 (3):268-292. http://dx.doi.org/10.4067/S071895162010000100005.

Yang, C.-Y., M.-1. Chang, S. C. Wu, and Y.-h. Shih. 2017. Partition uptake of a brominated diphenyl ether by the edible plant root of white radish (Raphanus sativusL.). Environmental Pollution 223:178-184. doi: 10.1016/j.envpol.2017.01.009.

Yuita, K., Y. Nobusawa, M. Shibuya, and S. Aso. 1982. Iodine, bromine and chlorine contents in soils and plants of Japan. I. Iodine, bromine and chlorine contents in soils and plants of the basin of the Miomote River. Soil Science and Plant Nutrition 28 (3):315-336. doi: 10.1080/00380768.1983.10434645. 


\section{Figure legend}

Figure 1. Dry biomass of leaves of rye (a), wheat (b), oat (c), and pea (d). The seedlings were germinated in water or in the media spiked with $\mathrm{KBr}$ and $\mathrm{NH}_{4} \mathrm{Br}$. The bars - mean dry biomass, ${ }^{\mathrm{I}} \quad$ - mean \pm 0.95 confidence interval. 
Figure 2. Concentration of $\mathrm{Br}$ in roots and leaves of the rye seedlings collected after germination in the media spiked with $\mathrm{KBr}$ (a) and $\mathrm{NH}_{4} \mathrm{Br}$ (b) during 5 and 13 days. The bars mean concentration of $\mathrm{Br}, \quad$ - mean \pm 0.95 confidence interval.

Figure 3. Values of $\mathrm{pH}$ of the growth media where oat (a), rye (b), wheat (c), and pea (d) seedlings were germinated in water or in the media spiked with $\mathrm{KBr}$ and $\mathrm{NH}_{4} \mathrm{Br}$. The bars mean $\mathrm{pH}$ values, ${ }^{\mathrm{I}} \quad$ - mean \pm 0.95 confidence interval. 

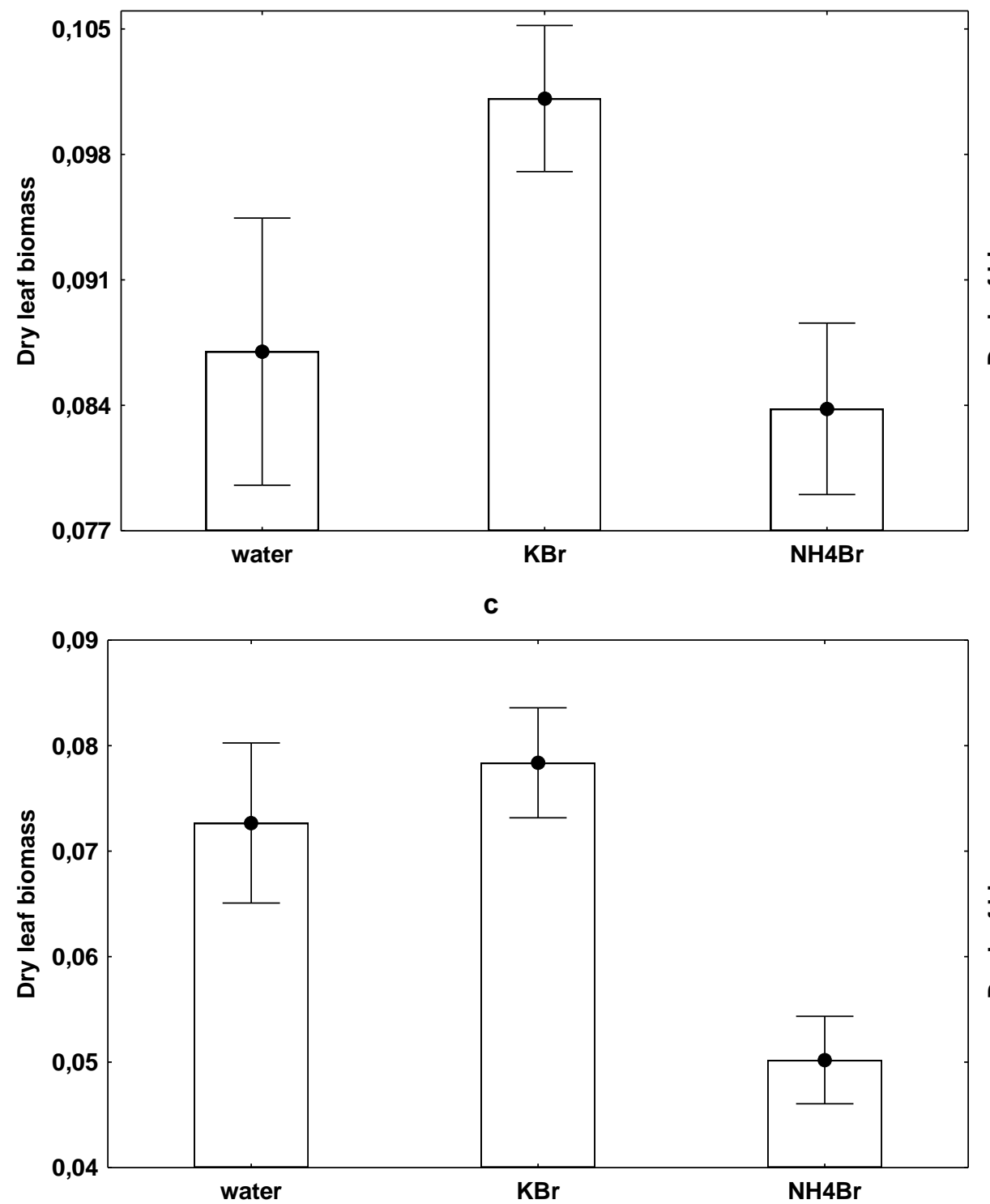
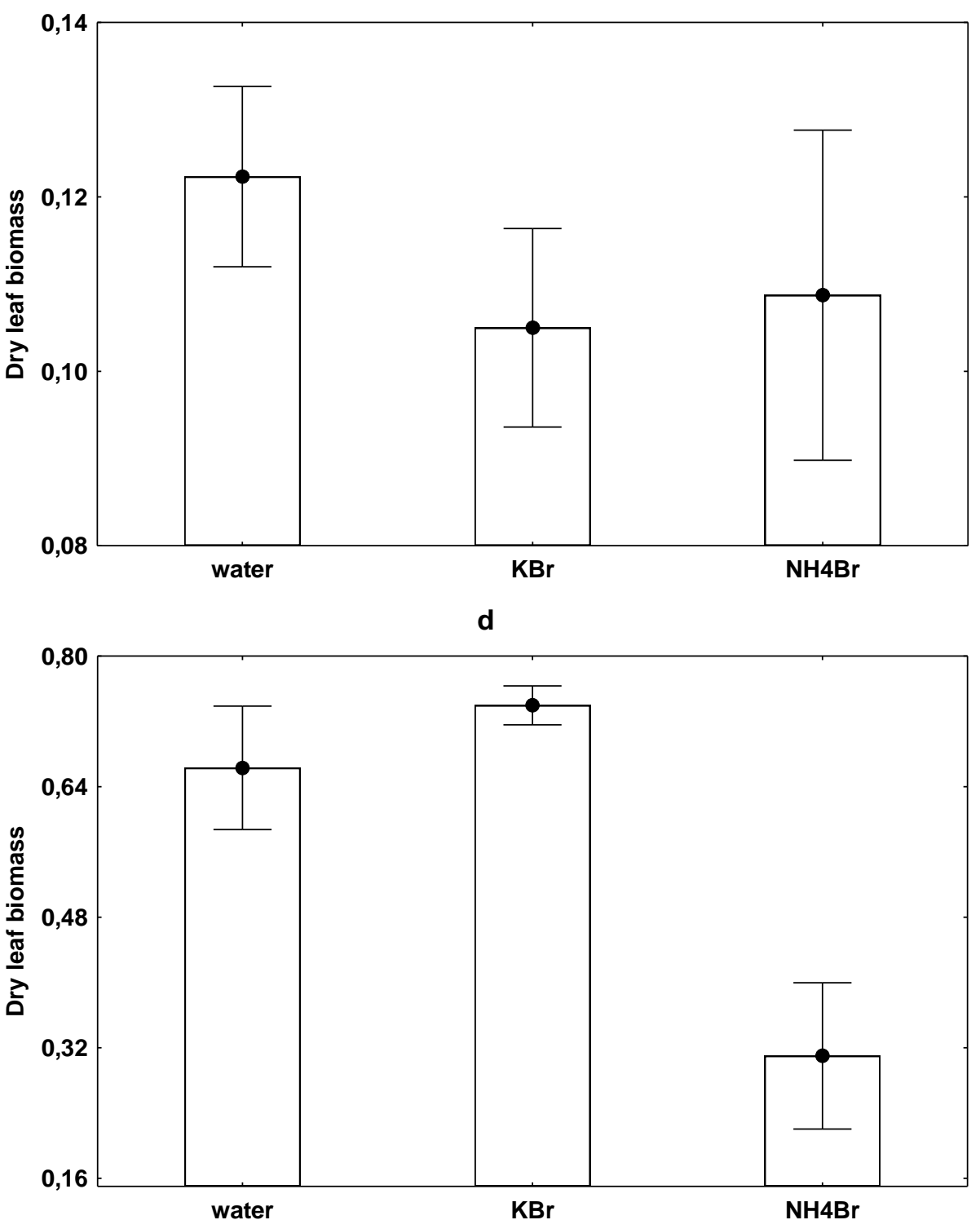

Figure 1 

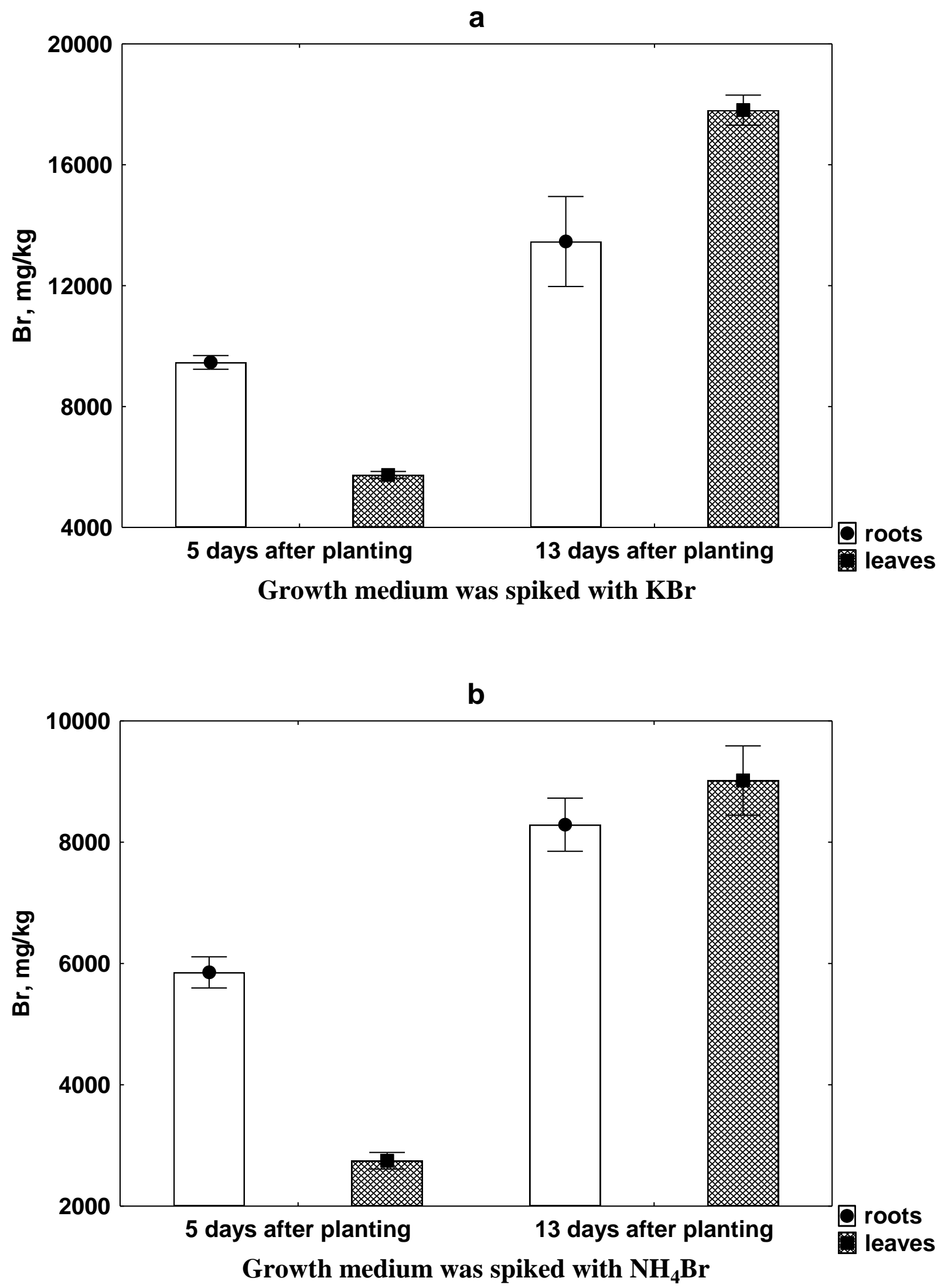

Figure 2 
a
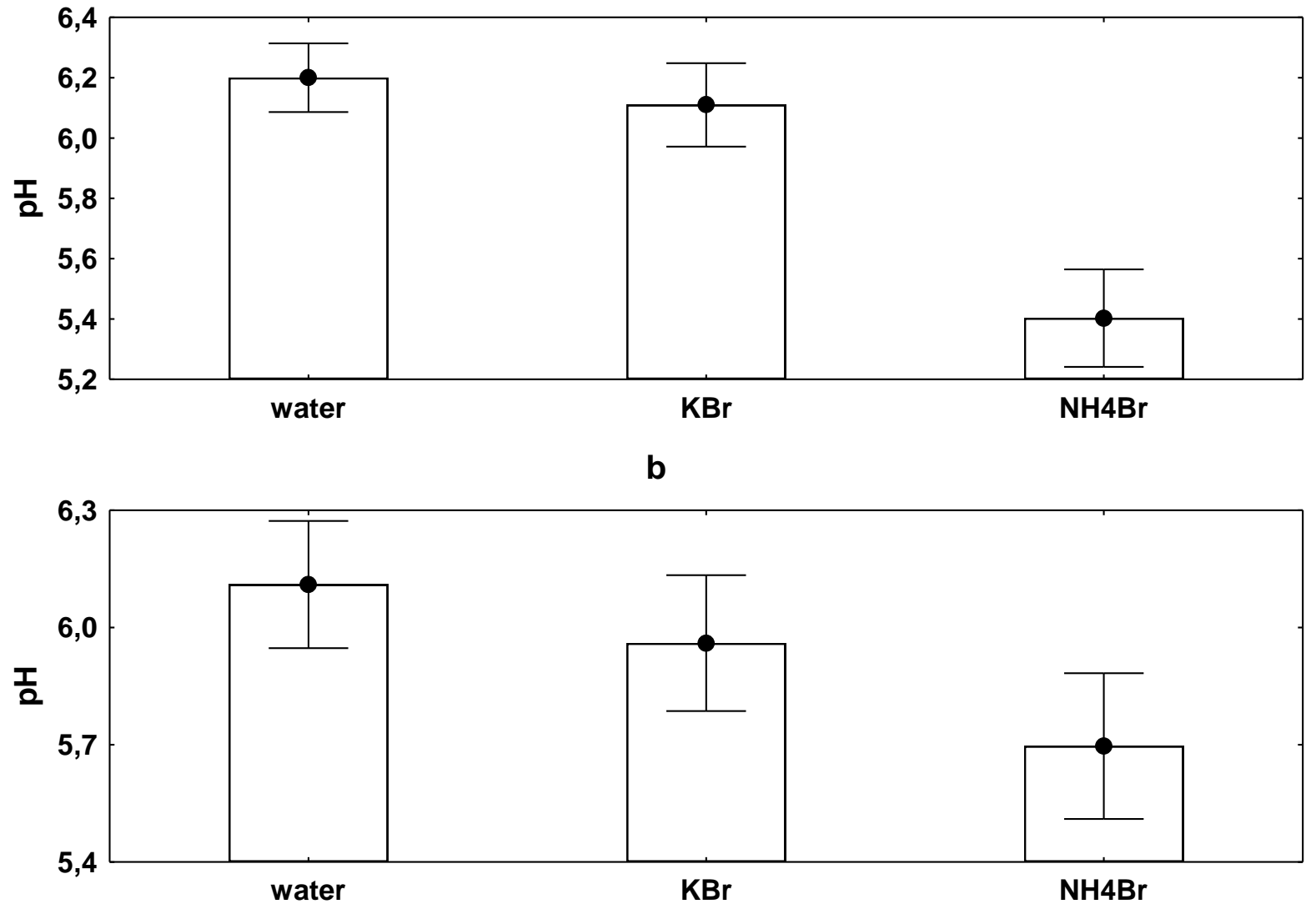

C
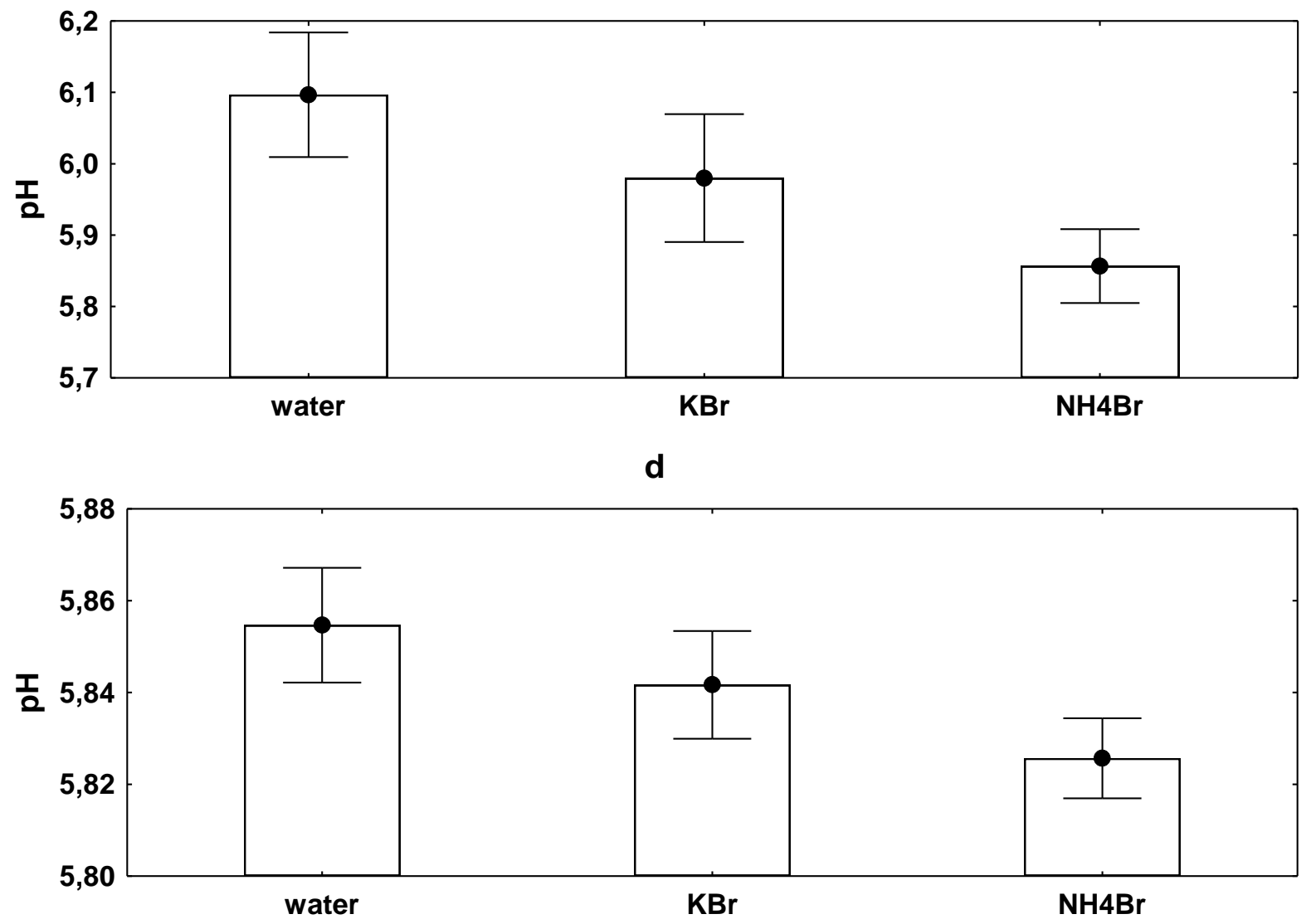

Figure 3 
Table 1. Mean concentrations $(\mathrm{n}=3)$ of elements in plants $\left(\mathrm{Br}-\mathrm{mg} \mathrm{kg}^{-1}\right.$, other elements $\left.-\mathrm{g} \mathrm{kg}^{-1}\right)$. 1 - no treatments, 2 and 3 - the growth media were spiked with $\mathrm{KBr}$ and $\mathrm{NH}_{4} \mathrm{Br}$, respectively.

* - differences between concentrations of elements in the seedlings germinated in water (no treatments) and in the media spiked with bromides were statistically significant $(\mathrm{P} \leq 0.05)$.

\begin{tabular}{|c|c|c|c|c|c|c|}
\hline & \multicolumn{6}{|c|}{ Oat } \\
\hline & \multicolumn{3}{|c|}{ Roots } & \multicolumn{3}{|c|}{ Leaves } \\
\hline & 1 & 2 & 3 & 1 & 2 & 3 \\
\hline $\mathrm{Br}$ & $33 \pm 6$ & $26470 \pm 450 *$ & $10020 \pm 140 *$ & $37 \pm 7$ & $30510 \pm 520 *$ & $23150 \pm 330 *$ \\
\hline $\mathrm{Cl}$ & $8.6 \pm 1.4$ & $9.9 \pm 2.0$ & $7.5 \pm 1.3$ & $13 \pm 3$ & $8.7 \pm 1.5$ & $10 \pm 2$ \\
\hline I & $1.3 \pm 0.4$ & $0.75 \pm 0.20$ & $2.1 \pm 0.6$ & $0.89 \pm 0.39$ & $0.26 \pm 0.16$ & $1.4 \pm 0.6$ \\
\hline $\mathrm{Na}$ & $7.7 \pm 1.3$ & $9.4 \pm 1.9$ & $6.0 \pm 1.2$ & $3.1 \pm 0.8$ & $1.6 \pm 0.7$ & $2.0 \pm 0.7$ \\
\hline $\mathrm{Mg}$ & $0.23 \pm 0.06$ & $0.26 \pm 0.05$ & $0.25 \pm 0.05$ & $0.20 \pm 0.01$ & $0.20 \pm 0.01$ & $0.20 \pm 0.01$ \\
\hline $\mathrm{P}$ & $7.9 \pm 1.3$ & $7.5 \pm 1.2$ & $12 \pm 3$ & $10 \pm 2$ & $7.3 \pm 0.8$ & $10 \pm 2$ \\
\hline $\mathrm{K}$ & $5.9 \pm 1.0$ & $9.6 \pm 2.7 *$ & $11 \pm 3 *$ & $15 \pm 6$ & $28 \pm 7 *$ & $26 \pm 6^{*}$ \\
\hline $\mathrm{Ca}$ & $0.45 \pm 0.08$ & $<0.20 *$ & $0.28 \pm 0.03 *$ & $0.23 \pm 0.02$ & $<0.20 *$ & $<0.20 *$ \\
\hline \multirow[t]{4}{*}{$\mathrm{Zn}$} & $149 \pm 16$ & $122 \pm 13$ & $187 \pm 20$ & $42 \pm 5$ & $43 \pm 5$ & $54 \pm 7$ \\
\hline & \multicolumn{6}{|c|}{ Rye } \\
\hline & \multicolumn{3}{|c|}{ Roots } & \multicolumn{3}{|c|}{ Leaves } \\
\hline & 1 & 2 & 3 & 1 & 2 & 3 \\
\hline $\mathrm{Br}$ & $33 \pm 6$ & $13710 \pm 170 *$ & $8221 \pm 90 *$ & $39 \pm 8$ & $17820 \pm 250 *$ & $8935 \pm 145^{*}$ \\
\hline $\mathrm{Cl}$ & $14 \pm 3$ & $6.3 \pm 1.2 *$ & $7.1 \pm 1.3^{*}$ & $7.4 \pm 1.3$ & $6.0 \pm 1.0$ & $6.6 \pm 1.1$ \\
\hline I & $0.52 \pm 0.06$ & $0.59 \pm 0.07$ & $1.0 \pm 0.1$ & $0.22 \pm 0.03$ & $<0.20$ & $<0.20$ \\
\hline $\mathrm{Na}$ & $6.5 \pm 1.3$ & $5.7 \pm 1.0$ & $3.3 \pm 0.7 *$ & $0.38 \pm 0.04$ & $0.32 \pm 0.03$ & $0.36 \pm 0.05$ \\
\hline $\mathrm{Mg}$ & $0.20 \pm 0.01$ & $0.33 \pm 0.04$ & $0.15 \pm 0.01$ & $0.64 \pm 0.07$ & $0.87 \pm 0.09$ & $0.82 \pm 0.08$ \\
\hline $\mathrm{P}$ & $4.7 \pm 1.0$ & $5.4 \pm 1.2$ & $5.3 \pm 1.3$ & $6.5 \pm 1.7$ & $5.2 \pm 1.0$ & $6.9 \pm 2.0$ \\
\hline K & $6.2 \pm 1.1$ & $11 \pm 2 *$ & $8.2 \pm 1.5$ & $15 \pm 4$ & $24 \pm 5^{*}$ & $18 \pm 4$ \\
\hline $\mathrm{Ca}$ & $0.36 \pm 0.04$ & $<0.20 *$ & $0.35 \pm 0.03$ & $0.33 \pm 0.04$ & $0.57 \pm 0.06$ & $0.43 \pm 0.05$ \\
\hline $\mathrm{Zn}$ & $84 \pm 9$ & $61 \pm 6$ & $65 \pm 7$ & $46 \pm 5$ & $38 \pm 4$ & $40 \pm 4$ \\
\hline & \multicolumn{6}{|c|}{ Wheat } \\
\hline & \multicolumn{3}{|c|}{ Roots } & \multicolumn{3}{|c|}{ Leaves } \\
\hline & 1 & 2 & 3 & 1 & 2 & 3 \\
\hline $\mathrm{Br}$ & $29 \pm 4$ & $10080 \pm 150 *$ & $4573 \pm 60 *$ & $86 \pm 11$ & $10680 \pm 160 *$ & $5344 \pm 70 *$ \\
\hline $\mathrm{Cl}$ & $9.3 \pm 1.5$ & $7.8 \pm 1.3$ & $5.3 \pm 1.2 *$ & $10 \pm 2$ & $9.3 \pm 1.6$ & $5.9 \pm 1.5 *$ \\
\hline I & $0.55 \pm 0.12$ & $1.3 \pm 0.5$ & $1.6 \pm 0.5$ & $<0.20$ & $<0.2$ & $<0.2$ \\
\hline $\mathrm{Na}$ & $7.2 \pm 1.2$ & $1.5 \pm 0.3 *$ & $4.1 \pm 1.0 *$ & $0.40 \pm 0.05$ & $0.35 \pm 0.04$ & $0.28 \pm 0.03$ \\
\hline $\mathrm{Mg}$ & $0.30 \pm 0.04$ & $0.17 \pm 0.02 *$ & $0.17 \pm 0.02 *$ & $0.31 \pm 0.04$ & $0.32 \pm 0.04$ & $0.17 \pm 0.02 *$ \\
\hline $\mathrm{P}$ & $3.5 \pm 0.9$ & $4.1 \pm 1.0$ & $4.3 \pm 1.0$ & $6.3 \pm 1.1$ & $7.7 \pm 1.3$ & $5.1 \pm 1.0$ \\
\hline $\mathrm{K}$ & $4.0 \pm 0.9$ & $25 \pm 3 *$ & $5.2 \pm 1.0$ & $20 \pm 3$ & $41 \pm 5^{*}$ & $15 \pm 2$ \\
\hline $\mathrm{Ca}$ & $0.48 \pm 0.05$ & $0.35 \pm 0.03 *$ & $0.23 \pm 0.03 *$ & $<0.20$ & $<0.20$ & $0.21 \pm 0.02$ \\
\hline \multirow[t]{4}{*}{$\mathrm{Zn}$} & $99 \pm 10$ & $66 \pm 8^{*}$ & $48 \pm 6 *$ & $37 \pm 5$ & $40 \pm 4$ & $34 \pm 6$ \\
\hline & \multicolumn{6}{|c|}{ Pea } \\
\hline & \multicolumn{3}{|c|}{ Roots } & \multicolumn{3}{|c|}{ Leaves } \\
\hline & 1 & 2 & 3 & 1 & 2 & 3 \\
\hline $\mathrm{Br}$ & $28 \pm 3$ & $6188 \pm 70 *$ & $2194 \pm 30 *$ & $4.8 \pm 1.2$ & $2972 \pm 30 *$ & $3796 \pm 40 *$ \\
\hline $\mathrm{Cl}$ & $3.9 \pm 0.5$ & $3.2 \pm 0.3$ & $<1 *$ & $2.2 \pm 0.3$ & $2.3 \pm 0.3$ & $1.5 \pm 0.2 *$ \\
\hline I & $0.54 \pm 0.13$ & $0.85 \pm 0.20$ & $0.29 \pm 0.20$ & $<0.2$ & $<0.2$ & $0.31 \pm 0.09$ \\
\hline $\mathrm{Na}$ & $0.40 \pm 0.08$ & $0.62 \pm 0.14$ & $0.44 \pm 0.09$ & $0.19 \pm 0.06$ & $0.09 \pm 0.05$ & $0.13 \pm 0.05$ \\
\hline $\mathrm{Mg}$ & $0.23 \pm 0.03$ & $0.24 \pm 0.03$ & $0.34 \pm 0.05$ & $0.20 \pm 0.02$ & $0.20 \pm 0.02$ & $0.27 \pm 0.03$ \\
\hline $\mathrm{P}$ & $7.1 \pm 1.3$ & $6.6 \pm 0.9$ & $7.7 \pm 1.2$ & $7.8 \pm 2.4$ & $15 \pm 5$ & $13 \pm 4$ \\
\hline $\mathrm{K}$ & $34 \pm 4$ & $39 \pm 5$ & $9.1 \pm 1.6^{*}$ & $25 \pm 3$ & $26 \pm 4$ & $30 \pm 4$ \\
\hline $\mathrm{Ca}$ & $0.25 \pm 0.03$ & $0.35 \pm 0.04$ & $<0.20 *$ & $0.24 \pm 0.04$ & $0.38 \pm 0.12$ & $<0.20 *$ \\
\hline $\mathrm{Zn}$ & $122 \pm 15$ & $102 \pm 12$ & $45 \pm 5 *$ & $58 \pm 6$ & $56 \pm 6$ & $56 \pm 7$ \\
\hline
\end{tabular}

